\title{
Association between islets of Langerhans and pancreatic ductal system in adult rat. Where endocrine and exocrine meet together?
}

\author{
E. Bertelli ${ }^{1}$, M. Regoli ${ }^{1}$, D. Orazioli ${ }^{1}$, M. Bendayan ${ }^{2}$ \\ ${ }^{1}$ Department of Biomedical Sciences, University of Siena, Siena, Italy \\ ${ }^{2}$ Department of Pathology and Cell Biology, University of Montreal, Montreal, Canada
}

\section{Abstract}

Aims/hypothesis. Studies on the functional and morphological relations between exocrine and endocrine pancreas have been conducted mainly to disclose the influence of islets of Langerhans on acinar parenchyma. Less attention has been paid to the relations occurring between islets and pancreatic ducts.

Methods. A series of consecutive sections of normal adult rat pancreas were double stained with islet (hormones) and duct (cytokeratin 20) markers. Electron microscopy was conducted to investigate the ultrastructural features of duct-islet relations and anti-insulin immunogold labelling was carried out to reveal the presence of insulin in the pancreatic duct system. Results. Consecutive double-stained sections demonstrated that $73.60 \pm 2.97 \%$ of the islets were attached to the ducts. For each series, $93.48 \pm 5.43 \%$ of the islets contacting the duct tree were associated with small-sized ducts or centroacinar cells. Electron microscopy revealed that some insulin and somatostatin cells do face the duct lumen. Insulin was detected within the duct lumen and in the endosomal compartment of the duct cells.

Conclusions/interpretation. The finding that most islets are connected with the duct system in the adult pancreas is discussed in terms of hormone secretion into the ducts, islet histogenesis and the relation among the three tissue components of the pancreas, the endocrine, the exocrine and the duct system. [Diabetologia (2001) 44: 575-584]

Keywords Pancreas, islet cells, duct epithelial cells, cytokeratin, glucagon, somatostatin, insulin, rat.
It is common to describe the endocrine and the exocrine pancreas as if they were two distinct and independent entities. However the pancreas is an integrated organ involved in the digestion and absorption of nutrients on the one hand, and in the regulation of blood glucose homeostasis, on the other. Most probably, the unique anatomical architecture of this organ, characterized by the dispersion of the endocrine component throughout the acinar parenchyma as hun-

Received: 12 October 2000 and in revised form: 18 January 2001

Corresponding author: Dr. Eugenio Bertelli, Dept. of Biomedical Sciences, University of Siena, Via Aldo Moro, I-53100 Siena, Italy

Abbreviations: AP, Alkaline phosphatase; CK20, cytokeratin 20; MAb, monoclonal antibody; PAb, polyclonal antibody dreds of thousands variable-sized clusters of endocrine cells (islets of Langerhans), has evolved to facilitate interactions between the two glandular components [1]. In order to determine reciprocal influences, many aspects of the relations occurring between exocrine and endocrine pancreas have been investigated in the past three decades $[2,3]$. Because of the observation that, in contrast to "tele-insular" acini, "periinsular" acini are formed by larger cells, containing more zymogen granules [2, 4-6], numerous studies have addressed the role(s) played by the islet hormones in tuning acinar cell secretion and the anatomical pathways, the so called "islet-acinar axis", through which this influence is exerted $[2,3,7]$. A large body of evidence indicates that a continuous insulo-acinar venous portal system conveys hormone enriched blood from the islets to the acinar parenchyma $[2,3,8,9]$. The amount of acinar tissue that is ac- 
tually involved in this portal system and its physiologic relevance are, however, still issues of debate $[10$, $11]$.

In contrast, much less attention has been paid to the relations between the endocrine pancreas and the ductal system. In normal conditions, only "extrainsular" endocrine tissue, represented by single cells or small buds of endocrine cells, is usually thought to be associated with the duct lining [12-16]. Islets of Langerhans, by contrast, have been reported to be connected with the ductal system only in the fetal pancreas as a short-lived result of endocrine histogenesis [17-19]. In adults, the eventual retention and the extent of such associations is controversial $[20,21]$ because no specific study has addressed this subject, apart from one investigator's pioneer work in guinea pigs [22]. A study of this issue appears particularly important considering that islets of Langerhans differentiate and develop from precursor cells hosted in the duct lining. These precursors or stem cells are believed to persist in the pancreas of adult individuals within the wall of the duct system [23-25]. Moreover, experimental studies have indicated that islet hormones are possible modulators of ductal secretion $[26,27]$. Indeed, whereas insulin appears to increase secretin-induced pancreatic juice secretion [26-28], glucagon, pancreatic polypeptide as well as somatostatin seem to have an inhibitory affect on duct cell functions [26, 27]. Many other "non-classical" islet hormones such as pancreastatin, neuropeptide tyrosine (NPY) and peptide tyrosine tyrosine (YY) could also be involved in duct cell secretion [27], with peptide YY, in particular, inhibiting spontaneous and secretin-stimulated bicarbonate secretion [29].

In recent studies, cytokeratin 20 (CK20) has been found to be expressed by all rat pancreatic duct cells (including centroacinar cells) regardless of the size of the ducts [30,31]. Taking advantage of cytokeratin 20's reliability as a ductal marker, we studied the extent of the topographical associations occurring between islets and ducts in the adult rat pancreas. Using double immunocytochemical labellings, which reveal both CK20 and islet hormone immunoreactive cells, we were able to demonstrate that most islets of Langerhans of the adult rat pancreas are directly connected with the pancreatic ductal system. This finding adds a new and important piece of information to the mosaic of the multiple relations occurring among the different components of the pancreas.

\section{Materials and methods}

Antibodies. Rabbit polyclonal antibodies (PAb) to somatostatin and glucagon were purchased from Novocastra Lab. (Newcastle upon Tyne, UK). Guinea pig anti-bovine insulin PAb was from Miles Biochemical (Elkart, NJ, USA). Monoclonal antibody (MAb) anti-cytokeratin 20 (CK20) was obtained from DAKO (Glostrup, Denmark). Alkaline phosphatase
(AP)-conjugated anti-rabbit IgG was from Roche Diagnostics (Monza, Italy) and AP-conjugated rat serum absorbed antimouse $\operatorname{IgG}$ from Sigma-Aldrich (Milan, Italy).

Animals and tissues. A total of 10 male adult Sprague-Dawley rats (3 to 9 months of age), fed with a standard diet, were used for this study. Principles of laboratory animal care were followed as well as the Italian law on animal experiments. After anaesthesia, four animals were killed by decapitation and the pancreatic tissue was sampled. The pancreas of each animal was divided into four pieces, fixed overnight in $1 \%$ glutaraldehyde, dehydrated and embedded in methylmethacrylate. The pancreas of three other animals were fixed for $2 \mathrm{~h}$ in Bouin's fluid, dehydrated and embedded in paraffin.

Tissues from three additional rats were used for electron microscopy. Perfusion was carried out for $20 \mathrm{~min}$ with $1 \%$ glutaraldehyde in $0.1 \mathrm{~mol} / \mathrm{l}$ sodium cacodylate buffer $(\mathrm{pH} 7.35)$ through the thoracic aorta. The pancreas was sampled, trimmed, further fixed for $2 \mathrm{~h}$ with the same fixative at $4{ }^{\circ} \mathrm{C}$, postfixed with $1 \% \mathrm{OsO}_{4}$ in cacodylate buffer for $2 \mathrm{~h}$ at $4{ }^{\circ} \mathrm{C}$, dehydrated and embedded in Epon 812.

Conventional histology, immunocytochemistry and transmission electron microscopy. Blocks of methylmethacrylate-embedded pancreatic tissue were cut leaving a step between each section for a total length of about $100 \mu \mathrm{m}$. Thirty random sections $(3.5 \mu \mathrm{m}$ thick) were routinely stained with $0.1 \%$ toluidine blue.

A total of 5 series of 25 consecutive sections ( $4 \mu \mathrm{m}$ thick) were cut from five different blocks of paraffin-embedded pancreas and used for immunocytochemistry. The first section of each series and the last one of the fifth series were considered as "random sections". Double immunocytochemical staining was carried out with the anti-CK20 MAb and with a cocktail of anti-somatostatin and anti-glucagon antisera. Sections were deparaffinazed, rehydrated, treated with $0.1 \%$ trypsin to retrieve CK20 antigenicity as previously reported [31], washed in PBS and incubated overnight at $4{ }^{\circ} \mathrm{C}$ with the anti-CK20 $\mathrm{MAb}$ (dilution 1/100). After rinsing with PBS, sections were incubated with AP-conjugated anti-mouse IgG and the AP reaction was developed with NBT/BCIP stock solution as chromogen diluted in $0.1 \mathrm{~mol} / \mathrm{l}$ TRIS buffer, $\mathrm{pH} 9.5,0.05 \mathrm{~mol} / \mathrm{l}$ $\mathrm{MgCl}_{2}, 0.1 \mathrm{~mol} / \mathrm{l} \mathrm{NaCl}, 2 \mathrm{mmol} / \mathrm{l}$ levamisole. Slides were then rinsed with distilled water to stop the reaction, equilibrated with PBS, and incubated with $0.25 \mathrm{~mol} / 1$ EDTA for $30 \mathrm{~min}$ to inactivate AP as previously reported [32]. After washing with PBS, slides were incubated overnight at $4{ }^{\circ} \mathrm{C}$ with the cocktail of anti-somatostatin and anti-glucagon antibodies both at a dilution of $1 / 50$. Sections were subsequently rinsed in PBS, incubated with AP-conjugated anti-rabbit $\mathrm{IgG}$ and the reaction was developed with Fast-Red tablets (Sigma-Aldrich, Milan, Italy).

For transmission electron microscopic analysis, consecutive ultrathin sections were routinely stained and observed with a Philips 201 or 410 electron microscope. For the immunocytochemical detection of insulin at the electron microscope level, we followed previously published techniques [7]. Briefly, ultrathin sections of $1 \%$ glutaraldehyde- $1 \% \mathrm{OsO}_{4}$ fixed, epon-embedded adult rat pancreatic tissue were treated with a saturated aqueous solution of sodium metaperiodate followed, after rinsing with PBS, by a $2 \mathrm{~h}$ incubation with a guinea-pig anti-bovine insulin antibody (dilution 1/200). After rinsing with PBS, the sections were incubated with the protein A-gold complex formed by $10 \mathrm{~nm}$ gold particles.

Quantitative evaluation of duct-islet associations. Islets of Langerhans were identified on $0.1 \%$ toluidine blue-stained 
sections by their general morphology (i.e. less basophilic staining properties compared with the surrounding tissue, general arrangement of secretory cells in cordon-like structures compared with the acinar grouping of the exocrine cells, absence of zymogen granules). By these criteria, islets showing a diameter as small as $35 \mu \mathrm{m}$ could be detected. On immunocytochemically double-stained sections, islets were identified by the presence of at least two red-stained cells (alpha or delta cells), by the absence of zymogen granules and by the general cordon-like arrangement of secretory cells around the blood capillaries. On this basis, we could detect islets with a diameter as small as $30 \mu \mathrm{m}$.

On random sections, either conventionally stained or immunocitochemically double-stained, all detectable islets were counted and reported as the number of islet profiles per $\mathrm{mm}^{2}$ of section area. The area of the sections was calculated with the Scion Image Beta 4.02 software package (Scion, Frederick, Md., USA). On the same sections, islets associated with ducts (with no structures or space interposed between islet and duct cells) were counted and expressed as percentage according to the following formula:

$\mathrm{X} \%=\mathrm{I}_{\mathrm{D}} / \mathrm{I}_{\mathrm{T}} \times 100$

$\left(\mathrm{I}_{\mathrm{D}}=\right.$ Islets associated with ducts, $\mathrm{I}_{\mathrm{T}}=$ Total number of spotted islets).

For the series of consecutive sections, we used the same formula but, in this case, care was taken to generate the total number of spotted islets counting each islet only once. To accomplish this, all the islets detectable on each section were numbered in order to identify them in the following slides. In this way, each islet was followed in its spatial development and checked for any association with duct cells that were categorised according to their positions on the duct tree: large ducts, middle-sized ducts, small ducts or centroacinar cell population.

\section{Results}

We first studied 25 routinely toluidine blue stained, randomly cut, pancreatic sections from methylmethacrylate-embedded tissues: an average of $23.08 \pm$ 8.05 islets of Langerhans were observed on each section (corresponding to an average of 1.009 islet profiles $/ \mathrm{mm}^{2}$ ), $33.28 \% \pm 8.28 \%$ of them appeared to be associated with excretory ducts (Fig 1). On the whole, 593 islets of Langerhans were detected and 203 of them were associated with the duct system. However, because the small ducts and the centroacinar cells are difficult to identify, we decided to label duct cells and peripheral islet endocrine cells with specific markers and to double-stain sections obtained from paraffin-embedded tissues. As CK20 was previously reported to be selectively expressed by duct and centroacinar cells [30, 31], we doublestained 5 series of 25 consecutive sections with the anti-CK20 and with a cocktail of anti-somatostatin and anti-glucagon antibodies (Fig.2). The first section of each series and the last one of the fifth series were observed separately and considered to be "random sections". By this technique, we identified an average of $60.2 \pm 4.82$ islets of Langerhans on each ran-
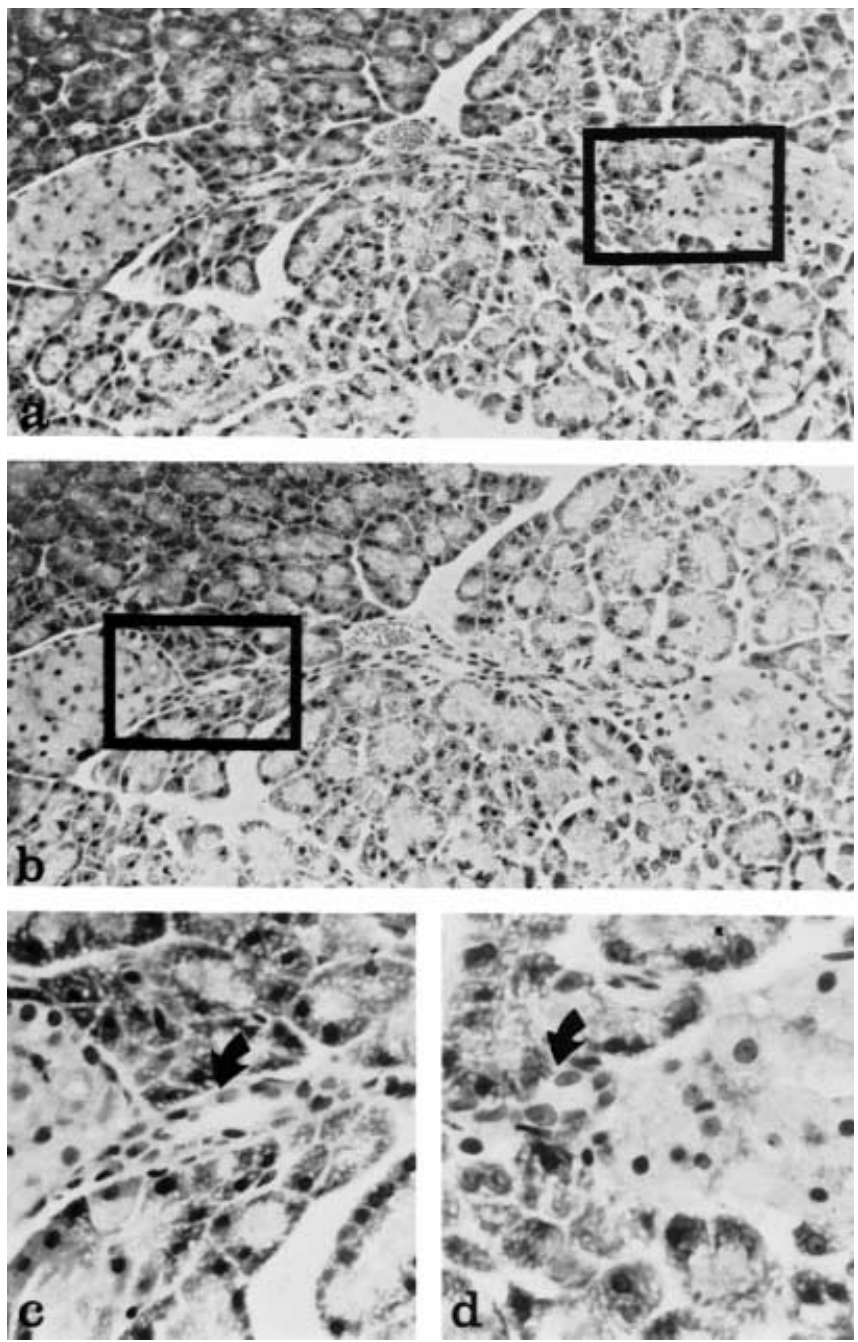

Fig. 1. Consecutive sections of adult rat pancreas. Arrows, duct a, b) Two islets of Langerhans seem to be joined together by a long intralobular duct (arrows). $\times 120$. c) Higher magnification of the framed area in $\mathbf{b} . \times 240$. d) Higher magnification of the framed area in $\mathbf{a} . \times 240$

dom section (corresponding to an average of 1.091 islet profiles $/ \mathrm{mm}^{2}$ ) and $40.83 \pm 7.41 \%$ of them were found to be associated with excretory ducts as identified by the CK20 staining. This type of approach, however, even though it increased the number of islets that could be shown to be in contact with the duct system, only allowed the identification of the associations present on a single plane of section. To approximate the detection of the real number of islets associated with the ductal system, we decided to study a series of consecutive sections. Using this technique, we were able to identify $184.2 \pm 33.74$ islets of Langerhans for each series and to find $73.60 \pm 2.97 \%$ of them in contact with the ductal tree. On the whole, 921 islets were identified with 680 of them associated with the duct system. This type of evaluation, however, does mask some regional differences since $55 \%$ of the islets that apparently 

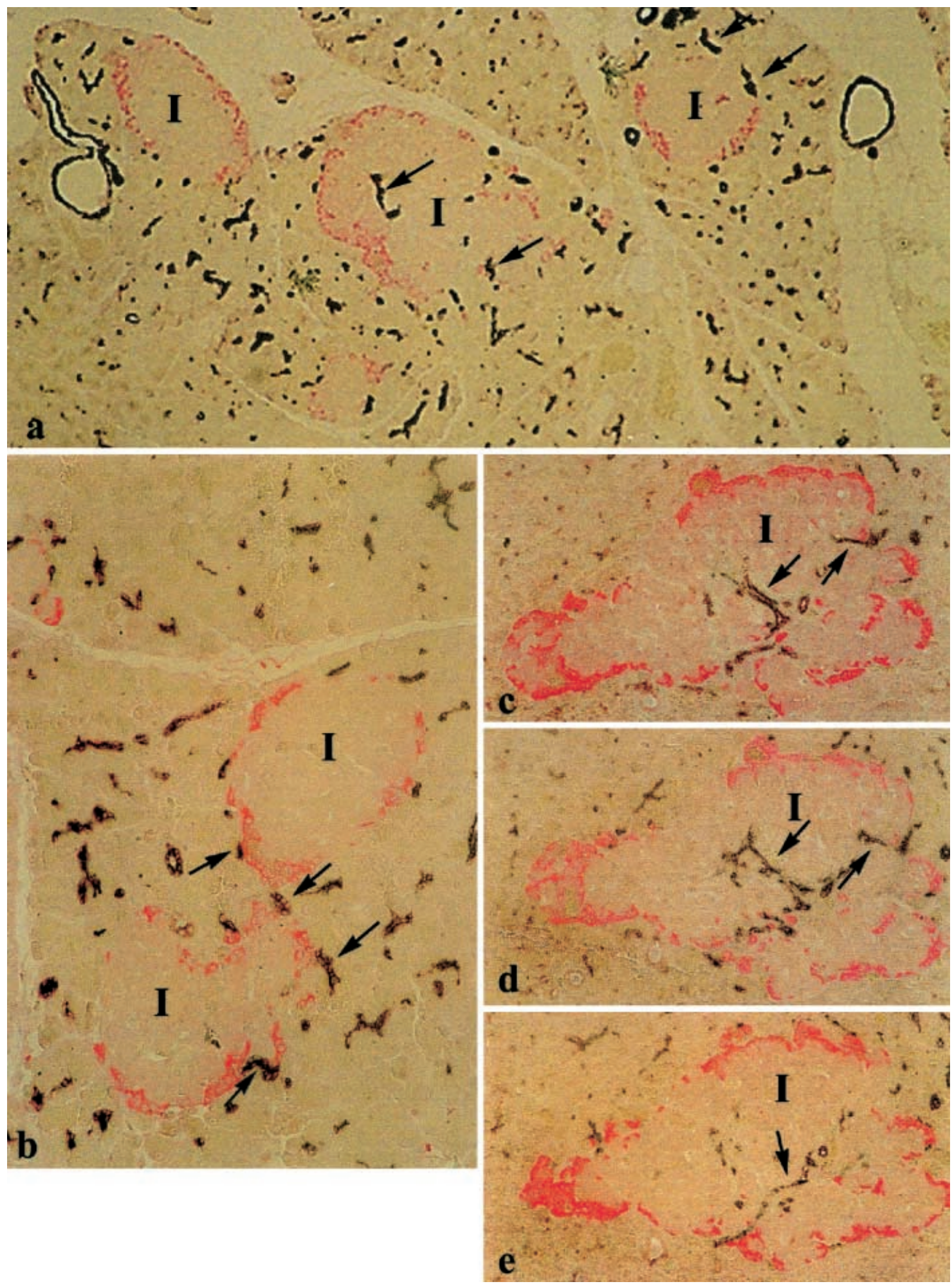

Fig. 2. Sections of adult rat pancreas double-stained with a cocktail of anti-glucagon and anti-somatostatin antibodies (red) and with anti-CK20 antibody (brown). a) Low magnification of several islets of Langerhans (I), outlined by the redstained cells, which appear to be associated with small-sized ducts and centroacinar cells (arrows). $\times 100$. b) Two islets of
Langerhans show several points of connection with the ductal tree (arrows) which is mainly associated with alpha and delta cells. $\times 150$. c, d, e) Three sections passing through the same islet of Langerhans (I) penetrated by a small duct (arrows). Within the islet the duct gives off few smaller ductules that seem to be blind-ended $(\times 100)$ 

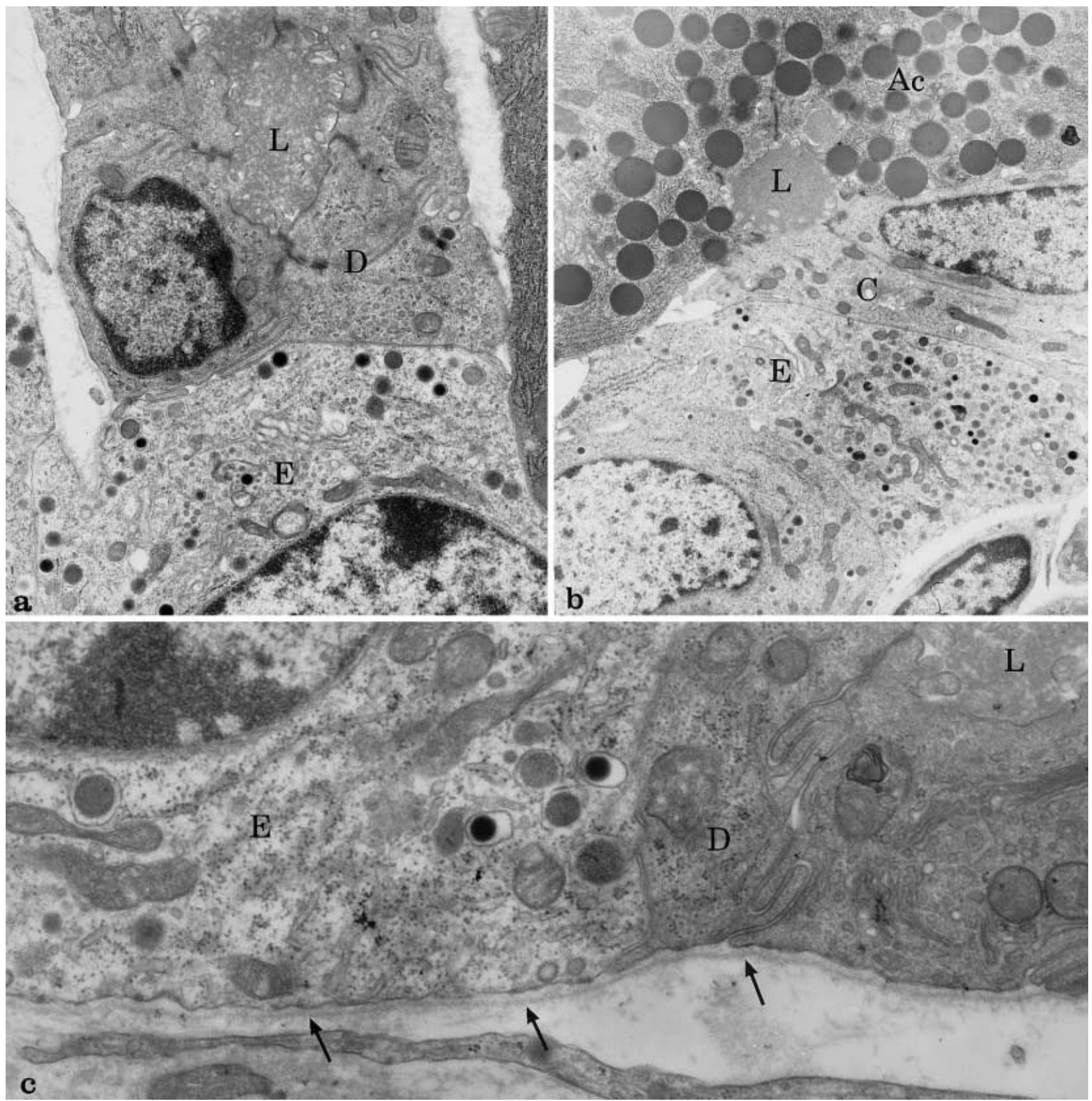

Fig.3. TEM micrographs of sections passing through the points of contact between two islets of Langerhans and the ductal tree. No basement membrane is interposed between the islets and the ductal cells. a) A small duct (D) is associated with an alpha cell $(\mathrm{E}) . \mathrm{L}=$ ductal lumen. $\times 12,000$. b) A pancreatic acinus (Ac) is closed by a centroacinar cell $(C)$ which outlines the lumen (L) and makes contact with the endocrine cells (E) of the islet. $\times 5,600$. c) Adjacent endocrine (E) and duct (D) cells sharing the same basement membrane (arrows). L, duct lumen. $\times 18,000$ did not make any contact with ductal cells were located at the periphery of the tissue sections, prompted to staining artefacts. In particular, CK20 antigenicity appeared more difficult to retrieve because of stronger fixation.

A more detailed analysis of the type of ducts that were more frequently in relation with the islets of Langerhans showed that the great majority of contacts involved centroacinar cells or small-sized ducts (Table 1). For each series of sections, $93.48 \pm 5.43 \%$ of the islets contacting the ductal system were in relation with the most proximal part of the ductal tree (centroacinar cells or small-sized ducts), regardless of the size of the islets. 

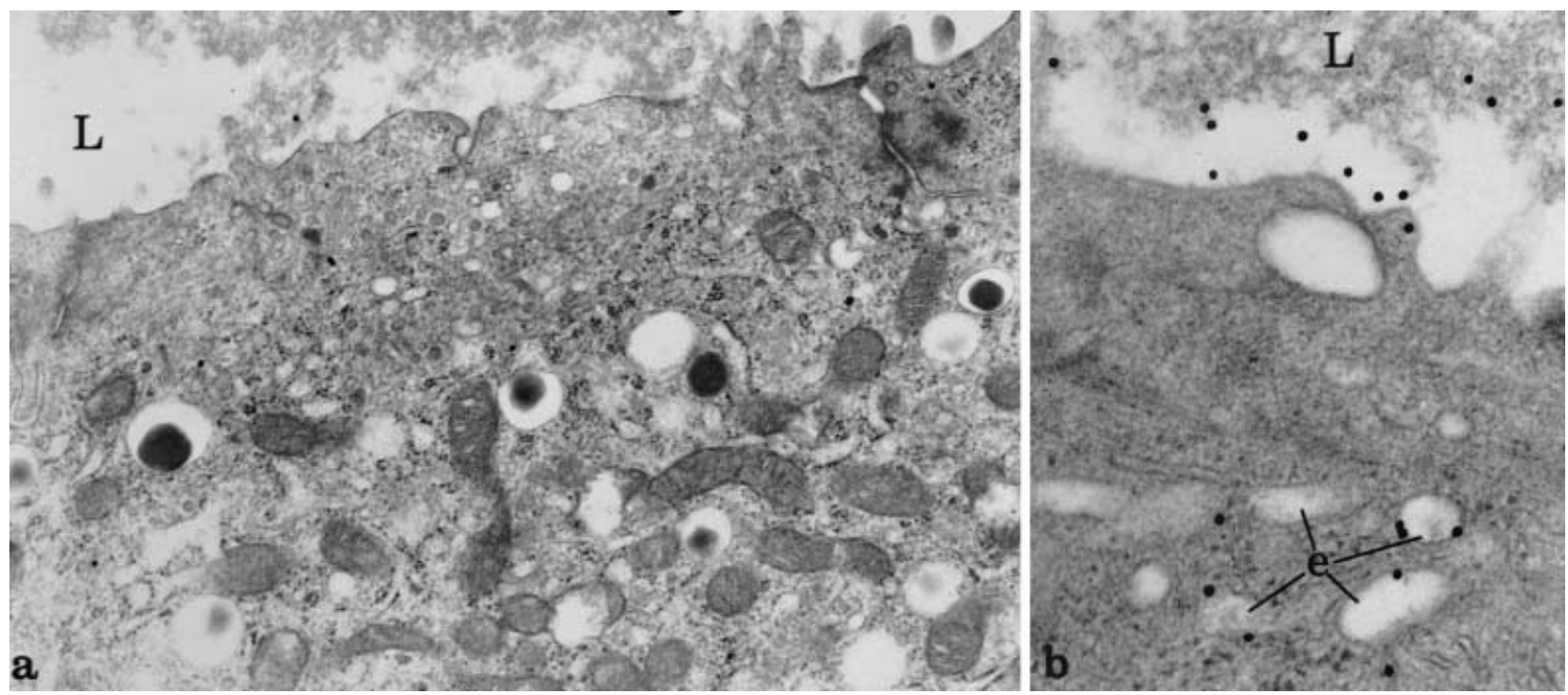

Fig.4. a TEM micrograph of the apical portion of a beta cell facing the duct lumen. The beta cell, belonging to a small islet of Langerhans is also provided with few microvilli on the right side of the luminal plasmalemma. $\times 18,000$. b Immunoelectron microscopy with anti-insulin antibody of duct cell. The $10 \mathrm{~nm}$. gold particles are prevalently located in the duct lumen (L) and label some vesicles of the endosomal compartment (e) of the duct cell. $\times 65,000$

Morphological aspects of duct-islet associations. A visual confirmation of the high frequency of association between ducts and islets is given by the general view of a large portion of a double-stained section (Fig. 2a). As mentioned above, most of the islets contacting the ductal tree were associated with centroacinar cells or small-sized ducts (Fig. 2a, b). Duct cells appeared, in this case, to be attached to the periphery of the islets and thus contacted alpha and delta cells more frequently (Fig.2b). The number of contacts that each islet made with the ductal tree varied. Several points of contact were common regardless of the size of the islet (Figs. 2a, b). Even though lateral attachments of the duct to the islets was the most frequent pattern of association, in a remarkable number of cases $(6 \%)$ small-sized ducts, along with blood ves- sels, were seen to enter the islets through thin connective septa (Fig.2c, d, e). Before leaving the islets, these ducts formed at least one loop and usually gave off smaller ducts that contacted directly the endocrine cells (in this case beta cells). They eventually ended as single CK20 immuno-reactive cells (Fig. 2c, $\mathrm{d}, \mathrm{e})$.

Transmission electron microscopic analysis of contacts between islet and duct cells confirmed that these cells were joined together by intercellular junctions, without any basement membrane or fibroblastic process interposed between them (Fig. 3a, b). At these points of contact, ductal basement membrane appeared to be continuous with the one surrounding the islets (Fig. 3c). Although beta and delta cells could face the duct lumina, alpha cells were always separated by at least a slender cytoplasmic expansion of duct or centroacinar cells. Intercellular junctions between endocrine and duct cells appeared more developed when participating in sealing the duct lumina (as the case of junctions between duct and insulin cells). Beta cells facing the lumen displayed a large set of coated pits, caveolae, cytoplasmic vesicles and tubulo-vesicular structures at or close to the luminal membrane reflecting an intense endocytotic activity (Fig. 4a).
Table 1. Associations between islets of Langerhans and the different sections of the ductal tree. Each line describes the amount (and the relative percentages) of associations occurring between the islets of Langerhans detected on each series of consecutive sections (first column) and the different sec- tions of the ductal tree (second column, CAC $=$ Centroacinar cells; third column, small-sized ducts; fourth column, CAC and small-sized ducts; fifth column, middle-sized ducts; sixth column, large ducts)

\begin{tabular}{lllcll}
\hline Series of sections & CAC & Small ducts & CAC/Small ducts & Mid-sized ducts & Large ducts \\
\hline I (128 islets) & $80(62.5 \%)$ & $37(28.90 \%)$ & $8(6.25 \%)$ & $3(1.56 \%)$ & 0 \\
II (146 islets) & $75(51.36 \%)$ & $51(34.93 \%)$ & $9(7.03 \%)$ & $6(3.42 \%)$ & $5(3.42 \%)$ \\
III (137 islets) & $79(57.66)$ & $32(23.35 \%)$ & $5(3.64 \%)$ & $9(4.37 \%)$ & $2(1.45 \%)$ \\
IV (166 islets) & $68(40.96 \%)$ & $50(30.12 \%)$ & $39(23.4 \%)$ & $7(3.64 \%)$ & $2(1.20 \%)$ \\
V (103 islets) & $48(46.60 \%)$ & $36(34.95 \%)$ & $17(16.50 \%)$ & $2(1.94 \%)$ & 0 \\
\hline
\end{tabular}




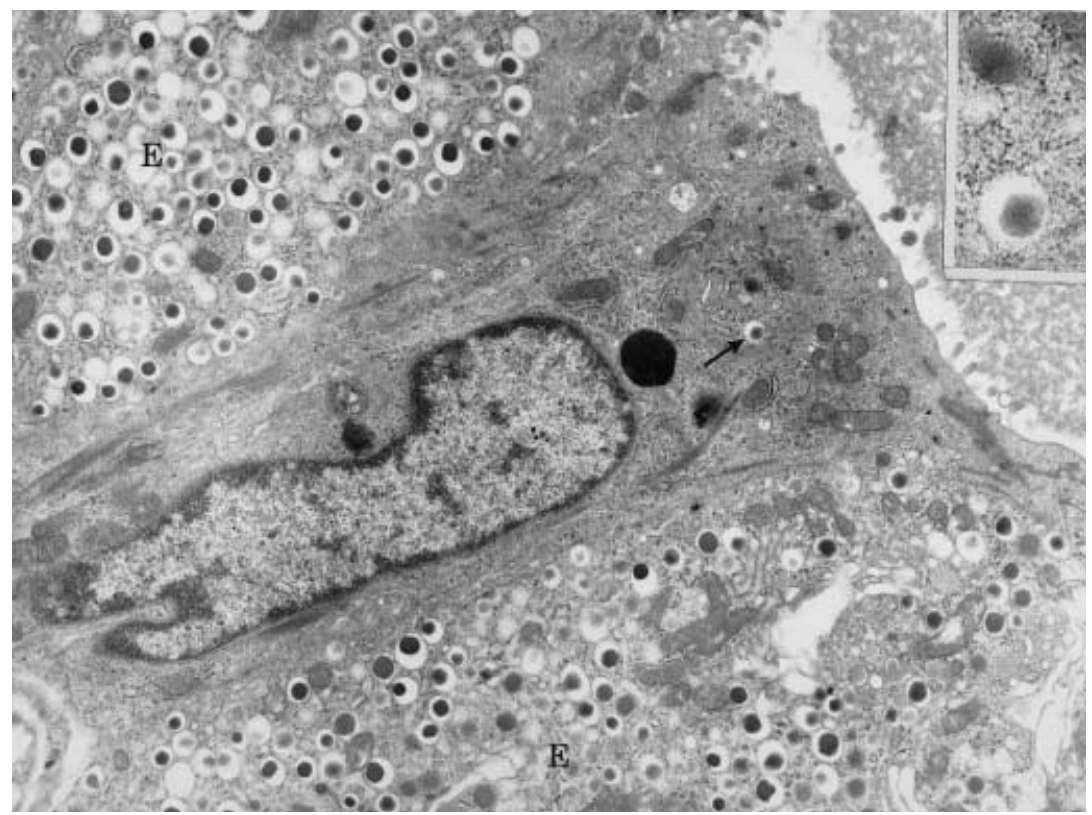

Fig. 5. TEM micrograph of an islet of Langerhans facing the lumen (L) of a middle-sized duct. A duct cell, located among the endocrine cells (E), shows a vesicle (arrow) closely resembling the insulin granules belonging to the adjacent cells. $\times 11,000$. Inset, high magnification of the presumptive insulin granule. $\times 40,000$

Electron microscopic immunocytochemical detection of insulin in pancreatic tissue lead to the labelling by gold particles of all beta cells including those lining the duct system. The labelling was present in all the cellular compartments involved in insulin secretion as previously reported (33). Of interest was the specific labelling found over the pancreatic duct lumen, in particular over the flocculent material present in the lumen, which corresponds to the pancreatic juice (Fig. 4b). Although of low intensity, labelling was also present within the epithelial cells lining the duct tree and was restricted to the endosomal compartment of the epithelial cells (Fig. 4b).

Occasionally, cells displaying a possible suggestive mixed duct-endocrine phenotype were observed at the sites of contact between ducts and islets (Fig 5).

\section{Discussion}

In contrast to the currently accepted notion that islets of Langerhans detach from the duct tree and migrate within the exocrine tissue along with the development of the gland $[19,30,34-40]$, our study demonstrates that the great majority of the islets remain connected with the ductal tree in the adult rat pancreas. This finding is in contrast with a recent investigation on human pancreas where only $1.3 \%$ of them were referred to as really connected with the duct sys- tem [38] even though half of the islets were found to be located in proximity to the ducts. Even though we cannot rule out differences between species, these conflicting results are probably because of the differences in the techniques employed. As a matter of fact, $93 \%$ of the contacts that we observed between islets and the duct tree involved centroacinar cells and small-sized ducts which are difficult to identify without the use of immunocytochemical markers. Our study has shown that the technical approach is crucial in demonstrating the extent of islet-duct association. Indeed, in this study, routine histology revealed only $33 \%$ of the islets in contact with duct cells. Even the application of immunocytochemical double-staining on random sections failed to increase that frequency greatly ( $41 \%)$. Only the use of series of consecutive double-stained sections, which on the whole explore a large portion (but not the entire) of the islets, revealed that $73 \%$ of the islets are associated with the duct system. Furthermore, even with this approach, we were not able to explore the entire islet surface that could contact the ducts. Thus, a higher percentage of associations cannot be excluded. Moreover, about half of the islets we failed to find in contact with the duct cells were located at the periphery of the sections, exposed to stronger fixation and harsher dehydration conditions that could impair the optimal retrieving of CK20 antigenicity interfering with the cytochemical stainings as previously reported $[30,31]$.

Endocrine cells have been previously reported to lie in the epithelial lining of pancreatic ducts as single elements $[12,13]$ as well as to protrude as small buds into the surrounding tissue [14]. In the former case, cells were classified to be either an "open" or a "closed type" depending on their ability to face the duct lumen. Beta and delta cells were found to be 
"open types" whereas alpha and PP cells were "closed types". Remarkably, in our study, all the islet cells observed in contact with the duct lining had the same pattern because only beta and delta cells were found facing directly the duct lumen. The reason for this consistency is not known but most probably related to functional properties of each cell type or with their ability to form well-developed intercellular junctional complexes that can efficiently seal the lumen of the ducts or both.

The finding that the association between islets and ducts is the rule more than the exception, raises the question of the role(s) that such connections play in the overall physiology of the pancreas. The peculiarity of an endocrine gland (considering the islets as one endocrine gland) that maintains its relation with the epithelium from which it arises is unusual when compared with other glands [41] and suggests the existence of a physiological stress that accounts for this particular arrangement. At the moment, we can only speculate on this issue and further studies will have to outline the exact part played by duct-islet associations. However, based on the current literature, a short list of probable functional hypothesis, can be put forward. These include, firstly, the possibility that the islet cells that face the duct lumen (beta and delta open type cells) secrete their hormones into the pancreatic juice. This possibility, previously proposed [2,12-14], is supported by the presence of islet hormones in the pancreatic juice as reported in the present study or as detected by biochemical means [42-44]. Moreover, insulin receptors have been detected on intestinal epithelial cell membranes $[45,46]$ including their brush border $[47,48]$, suggesting concrete targets for the "exocrine" insulin secreted with the pancreatic juice that could have trophic effects on the intestinal epithelium. In addition, other targets could also be duct cells as they displayed insulin immunoreactivity in their apical endosomal compartment.

Secondly, the intense endocytotic activity present in those endocrine cells that face the duct lumina seems to indicate a remarkable uptake of pancreatic juice that could bring peculiar stimuli to the endocrine cells. Because of the existence of gap junctions among islet cells $[49,50]$, eventual transduction of signals coming from the duct lumen could spread to a larger population of islet cells. In this case, the Reg protein, an acinar cell product involved in islet cell regeneration [51-55] is a molecule that is secreted into the pancreatic juice but exerts its major action on islet cells by pathways that have not yet been clearly established. Duct open islet cells could therefore be a possibility. The loss of Reg protein or other trophic factors present in the pancreatic juice upon islet disconnection from the ducts could account for the disappointing results obtained by transplantation of purified islets in diabetic patients [23]. In contrast, transplantation of whole pancreas in which islets maintain their topographical relation with surrounding parenchyma appears more successful [23].

Thirdly, islets of Langerhans arise from precursor stem cells present in the embryonic pancreatic ducts $[19,30,56]$. Fetal and neonatal islets of Langerhans grow mainly from the continuous addition of newly differentiated cells arising from precursors hosted within the ducts rather than from a proliferation of differentiated islet-cells $[15,30,36,56]$. Thus, the persistence of these precursor cells in adult pancreas and their susceptibility to be reactivated are crucial issues for outlining new strategies in prevention and treatment of diabetes mellitus [23]. In this respect, the demonstration that islets ultimately do not detach from ducts, makes the sites of contact between ducts and islets of particular interest for the search of islet stem cells. Although extremely rare, the finding of cells displaying mixed duct-endocrine phenotypes in such a location suggests active endocrine histogenetic processes.

Last but not least, the contacts between islets and ducts could be the anatomical basis accounting for the influence that exocrine secretions are supposed to exert on the endocrine pancreas. The existence of such an influence is supported mainly by the notion that pancreatic insufficiency is followed by anatomopathologic alterations of the islets of Langerhans [57] and frequently by overt diabetes [3, 58, 59]. Thus, from an anatomical point of view, apart from the well-known "islet-acinar axis", an "acinar-islet axis" (including the duct system) could also exist closing the circle of interactions among the components of the pancreas as previously suggested [3]. The finding that islets are mainly associated with the most proximal sections of the ductal tree (centroacinar or small-sized duct) indicates that they have a relation with ducts draining portions of acinar tissue located in proximity to the islets themselves, maybe in the same portions of exocrine parenchyma (the peri-insular tissue) that are more influenced by islet hormones. If this were confirmed, the pancreas should be considered as a gland formed by the assembly of thousands of small morpho-functional units, each centred on an islet of Langerhans.

Acknowledgements. This work has been supported by the Medical Research Council of Canada (M. B.). We are grateful to Mrs. D. Gingras and Mr. J. Leveille for their technical support.

\section{References}

1. Henderson JR (1969) Why are the islets of Langerhans? Lancet 2: 469-470

2. Bendayan M (1990) Anatomic basis of islet-acinar interaction in the pancreas. Regul Pept Lett 2: 1-7

3. Creutzfeldt W, Fölsch UR, Stockmann F (1990) Clinical implications of islet-acinar interactions. Regul Pept Lett 2: 11-15 
4. Malaisse-Lagae F, Ravazzola M, Robberecht P, Van-Dermeers A, Malaisse WJ, Orci L (1975) Exocrine pancreas: evidence for topographic partition of secretory function. Science 190: 795-797

5. Bendayan M (1985) Morphological and immunocytochemical characterization of peri-insular and tele-insular acinar cells in the rat pancreas. Eur J Cell Biol 36: 263-268

6. Bendayan M, Ito S (1979) Immunohistochemical localization of exocrine enzymes in normal rat pancreas. J Histochem Cytochem 27: 1029-1034

7. Bendayan M (1993) Pathway of insulin in pancreatic tissue on its release by the B-cell. Am J Physiol 264: G187-G194

8. Fujita T (1973) Insulo-acinar portal system in the horse pancreas. Arch Histol Jpn 35: 161-171

9. Bonner-Weir S, Orci L (1982) New perspectives on the microvasculature of the islets of Langerhans in the rat. Diabetes 31: 883-889

10. Williams JA, Goldfine ID (1993) The insulin-acinar relation. In: Go VLW, Lebenthal E, DiMagno EP, Reber HA, Gardner JD, Scheele GA (eds) The pancreas biology, pathobiology, and disease. 2nd edn. Raven Press, New York, pp 789-802

11. Bonner-Weir S (1993) The microvasculature of the pancreas, with emphasis on that of the islets of Langerhans: anatomy and functional implications. In: Go VLW, Lebenthal E, DiMagno EP, Reber HA, Gardner JD, Scheele GA (eds) The pancreas biology, pathobiology, and disease. 2nd edn. Raven Press, New York, pp 759-768

12. Bendayan M (1987) Presence of the endocrine cells in pancreatic ducts. Pancreas 2: 393-397

13. Park I-S, Bendayan M (1992) Characterization of the endocrine cells in the pancreatic-bile duct system of the rat. Anat Rec 232: 247-256

14. Bertelli E, Regoli M, Bastianini A (1994) Endocrine tissue associated with the pancreatic ductal system: a light and electron microscopic study of the adult rat pancreas with special reference to a new endocrine arrangement. Anat Rec 239: 371-378

15. Wang RN, Bouwens L, Klöppel G (1994) Beta-cell proliferation in normal and streptozotocin-treated newborn rats: site, dynamics and capacity. Diabetologia 37: 1088-1096

16. Bouwens L, Pipeleers DG (1998) Extra-insular beta cells associated with ductules are frequent in adult human pancreas. Diabetologia 41: 629-633

17. Conklin JL (1962) Cytogenesis of the human pancreas. Am J Anat 111: 181-193

18. Liu HM, Potter EL (1962) Development of the human pancreas. Arch Pathol 74: 439-452

19. Pictet R, Rutter WJ (1972) Development of the embryonic endocrine pancreas. In: Steinert DF, Freinkel N (eds) Handbook of phisiology, sect 7 Endocrinology, Vol 1. American Physiological Society, Whashington, pp 25-66

20. Brunfeldt K, Hunhammar K, Skouby AP (1958) Studies on the vascular system of the islet of Langerhans. Acta Endocrinol 29: 473-480

21. Pour P (1978) Islet cells as a component of pancreatic ductal neoplasms. Am J Pathol 90: 295-316

22. Bensley RR (1911) Studies on the pancreas of the guinea pig. Am J Anat 12: 297-388

23. Rosenberg L (1995) In vivo cell transformation: neogenesis of beta cells from pancreatic ductal cells. Cell Transplant 4: 371-383

24. Bonner-Weir S, Baxter LA, Schuppin GT, Smith FE (1993) A second pathway of adult exocrine and endocrine pancreas. Diabetes 42: 1715-1720
25. Wang RN, Klöppel G, Bouwens L (1995) Duct- to islet-cell differentiation and islet growth in the pancreas of ductligated adult rats. Diabetologia 38: 1405-1411

26. Hasegawa H, Okabayashi Y, Koide M et al. (1993) Effect of islet hormones on secretin-stimulated exocrine secretion in isolated perfused rat pancreas. Dig Dis Sci 38: 1278-1283

27. Case RM, Argent BE (1993) Pancreatic duct cell secretion: control and mechanism of transport. In: Go VLW, Lebenthal E, DiMagno EP, Reber HA, Gardner JD, Scheele GA (eds) The pancreas biology, pathobiology, and disease. 2nd edn. Raven Press, New York, pp 301-350

28. Lee KY, Zhou L, Ren XS, Chang T-M, Chey WY (1990) An important role of endogenous insulin on exocrine pancreatic secretion. Am J Physiol 258: G268-G274

29. Pappas TN, Debas HT, Taylor IL (1985) Peptide YY metabolism and effect on pancreatic secretion on dog. Gastroenterology 89: 1387-1392

30. Bouwens L, Wang R-N, De Blay E, Pipeelers DG, Klöppel G (1994) Cytokeratins as markers of ductal cell differentiation and islet neogenesis in the neonatal rat pancreas. Diabetes 43: 1279-1283

31. Bouwens L, Braet F, Heimberg H (1995) Identification of rat pancreatic duct cells by their expression of cytokeratins 7,19 , and 20 in vivo and after isolation and culture. J Histochem Cytochem 43: 245-253

32. Deininger MH, Meyermann R (1998) Multiple epitope labelling by the exclusive use of alkaline phosphatase conjugates in immunohistochemistry. Histochem Cell Biol 110: 425-430

33. Bendayan M (1989) Ultrastructural localization of insulin and C-peptide antigenic sites in rat pancreatic B cell obtained by applying the quantitative high-resolution protein A-gold approach. Am J Anat 185: 205-216

34. Teitelman G, Lee JK (1987) Cell lineage analysis of pancreatic islet cell development: glucagon and insulin cells arise from catecholaminergic precursors present in the pancreatic duct. Dev Biol 121: 454-466

35. Teitelman G (1991) Cellular and molecular analysis of pancreatic islet cell lineage and differentiation. Recent Prog Horm Res 47: 259-297

36. Deltour L, Leduque P, Paldi A, Ripoche MA, Dubois P, Jami J (1991) Polyclonal origin of pancreatic islets in aggregation mouse chimaeras. Development 112: 1115-1121

37. Wang RN, Bouwens L, Klöppel G (1996) Beta-cell growth in adolescent and adult rats treated with streptozotocin during the neonatal period. Diabetologia 39: 548-557

38. Watanabe T, Yaegashi H, Koizumi M, Toyota T, Takahashi $\mathrm{T}$ (1999) Changing distribution of islets in the developing human pancreas: a computer-assisted three-dimensional reconstruction study. Pancreas 18: 349-354

39. Peters J, Jürgensen A, Klöppel G (2000) Ontogeny, differentiation and growth of the endocrine pancreas. Virchows Arch 436: 527-538

40. Gannong M, Ray MK, Van Zee K, Rausa F, Costa RH, Wright CVE (2000) Persistent expression of HNF6 in islet endocrine cells causes disrupted islet architecture and loss of beta cell function. Development 127: 2883-2895

41. Paulsen DF (1993) Basic Histology. 2nd edn. Appleton and Lange, Norwalk

42. Colon JM, Rouiller D, Boden G, Unger RH (1979) Characterization of immunoreactive components of insulin and somatostatin in canine pancreatic juice. FEBS Lett 105: 23-26

43. Ertan A, Taminato T, Akdamar K et al. (1981) Immunoreactive somatostatin in human pancreatic secretion. J Clin Endocrinol Metab 52: 589-591

44. Sarfati PD, Green GM, Brazeau P, Morisset J (1986) Presence of somatostatin-like immunoreactivity in rat pancre- 
atic juice: a physiological phenomenon. Can J Physiol Pharmacol 64: 539-544

45. Gallo-Payet N, Hugon JS (1984) Insulin receptors in isolated adult mouse intestinal cells:studies in vivo and in organ culture. Endocrinology 114: 1885-1894

46. Gingerich RL, Gilbert WR, Comens PG, Gavin JR (1987) Identification and characterization of insulin receptors in basolateral membranes of dog intestinal mucosa. Diabetes 36: 1124-1129

47. Pillion DJ, Ganapathy V, Leibach FH (1985) Identification of insulin receptors on the mucosal surface of colon epithelial cells. J Biol Chem 260: 5244-5247

48. Buts JP, De Keyser N, Marandi S et al. (1997) Expression of insulin receptors and of $60-\mathrm{kDa}$ receptor substrate in rat mature and immature enterocytes. Am J Physiol 273: G217-G226

49. Meda P, Santos RM, Atwater I (1986) Direct identification of electrophysiologically monitored cells within intact mouse islet of Langerhans. Diabetes 35: 232-236

50. Meda P (1996) The role of gap junction membrane channels in secretion and hormonal action. J Bioenerg Biomembr 28: 369-377

51. Miyaura C, Chen L, Appel L et al. (1991) Expression of reg/PSP, a pancreatic exocrine gene: relationship to changes in islet beta-cell mass. Mol Endocrinol 5: 226-234
52. Ohno T, Ishii C, Kato N et al. (1995) Increased expression of a regenerating (reg) gene protein in neonatal rat pancreas treated with streptozotocin. Endocr J 42: 649-653

53. Rafaeloff R, Barlow SW, Rosenberg L, Vinik AI (1995) Expression of Reg gene in the syrian golden hamster pancreatic islet regeneration model. Diabetologia 38: 906-913

54. Zenilman ME, Chen J, Danesh B, Zheng QH (1998) Characteristics of rat pancreatic regenerating protein. Surgery 124: 855-863

55. Sanchez D, Baeza N, Blouin R et al. (2000) Overexpression of reg gene in non-obese diabetic mouse pancreas during active diabetogenesis is retricted to exocrine tissue. $\mathrm{J}$ Histochem Cytochem 48: 1401-1410

56. Bouwens L, Lu WG, De Krijger R (1997) Proliferation and differentiation in the human fetal endocrine pancreas. Diabetologia 40: 398-404

57. Klöppel G, Bommer G, Commandeur G, Heitz Ph (1978) The endocrine pancreas in chronic pancreatitis. Virchows Arch 377: 154-174

58. Bank S, Marks IN, Vinik AI (1975) Clinical and hormonal aspects of pancreatic diabetes. Am J Gastroenterol 64: $13-22$

59. Kalthoff L, Layer P, Clain JE, DiMagno EP (1984) The course of alcoholic and nonalcoholic chronic pancreatitis. Dig Dis Sci 29: 953 